\title{
Macro and Microanatomical Structures of Lizard's Regenerate Tail (Mabouya multifasciata Kuhl, 1820)
}

\author{
Ardiana $^{1}$, Muhammad Ja'far Luthfi ${ }^{2}$, Nyoman Puniawati Soesilo ${ }^{3}$, Laila Ainun Nisa ${ }^{2}$, Risti Widyaningsih ${ }^{2}$ \\ ${ }^{1}$ Biology Department, ${ }^{2}$ Biology Education Department, Faculty of Science and Technology, UIN Sunan Kalijaga \\ Jl. Marsda Adisucipto No 1 Yogyakarta 55281, Indonesia. Tel. +62-274-540971, Fax. +62-274-519739 \\ ${ }^{3}$ Gadjah Mada University, Bulaksumur, Caturtunggal, Kec. Depok, Kabupaten Sleman, Daerah Istimewa Yogyakarta 55281 \\ "Email: lailaainunnisa67@gmail.com
}

\begin{abstract}
Lizards are animals that can do autotomy. Research on the autotomy of lizard's tail has been carried out, but few have examined about axial skeletons that focus on vertebrae caudales or arranged muscles. That is the background of this research. This research is expected to be a database for further research and as a comparison between animals that can perform other autotomies. This research intend to determine the macro and micro structures of the anatomical axial skeleton lizard's regenerate tail and to know the micro structures of anatomy muscular segmentation lizard's regenerate tail. The used methods are X-Ray, Alizarin Red S and Alcian Blue, Paraffin method with Hematoxylin-Eosin and Mallory Triple Strain staining. The result showed that the lizard's regenerate tail was darker than the original. On observations using X-Ray and Alizarin staining showed that the original tail is seen broad and have a Processus. The original lizard's tail is composed of bones, because it is red which shows perfectly calcified bones. While the regenerate of the lizard's tail is composed of bones in the form of long pipes which are red-colored because they have calcified from outside. Muscular segmentation of the original lizard's tail when viewed transversely has irregular segments. While the lizard's regenerate tail has 15 muscle segments. Muscles are composed of a collection of myotubes that become myotomes, each of myotomes confined by the myoseptum.
\end{abstract}

Keyword: Autotomy, Lizard, Macroanatomy, Microanatomy, Tail regenerate

\section{INTRODUCTION}

Every organism has certain ways to avoid its enemies. In some Lacertilia members they have a self-protection by doing autotomy, which breaking some part of their tail, and it called plain autotomy. Tail autotomy occurs when the animal is chased or the tail is captured. The part of the tail that is released will move for a while, attracting the attention of predators, while the animal escapes (Bustard, 1968; Bellairs and Bryant, 1985). Lacertilia member tail is composed of rows of vertebrae (vertebrae caudales), spinal cord located in the vertebral canal, perivertebral fat tissue, muscle layer, blood vessels, nerve fibers and skin along with scales (Soesilo, 1999).

Vertebrate skeleton is divided into three main parts, namely: axial skeleton, visceral skeleton and appendicular skeleton. Axial skeleton is the body's shaft framework which includes neurocranium, vertebrae, costae and sternum. The vertebrae are divided into 4 parts of the cervicales, thoracales, lumbales, sacrales, and caudales. This vertebrae caudales are often undergoes autotomy, because certain places along the tail are transverse fracture plains (Bustard, 1968).

Regeneration is the ability to replace lost, injured or damaged body parts. The regeneration process can be divided into three phases: wound healing and differentiation of blastema formation and growth; and differentiation and morphogenesis (Soesilo, 1992).

Most of the research on autotomy and regeneration focuses on the regeneration process and the role of the nervous system in the regeneration process. Until now there has not been much research on the macro and microstructure of regenerate lizard tails that have been regenerated. This study is hoped it can add to the data base for further research and can provide scientific data and information to science, especially in the field of anatomical histology.

Therefore it is interesting to study, to know how the macro and microstructure of skeleton anatomy of axial regenerate lizard tail is and how the microstructure of anatomy the segmentation of muscular regenerate lizard tail is.

\section{MATERIALS AND METHODS}

The tools used in this study are enclosures equipped with water and food, X-ray, surgical instruments, microscopes, ovens, paraffin ovens, microtomes, glass beaker, staining jar, flakon bottles, slides, glass cover, tissue, cotton, petri dish, slide warmer, gauze, tube, tube plug and thread. While the materials used in this study are: 25 lizards obtained from rice fields in Godean, crickets as lizards, Alcohol, Mallory Triple Stain, Alizarin Red S, Alcian Blue, $\mathrm{KOH}$, Acetone, Glycerin, Chloroform, Acetic Acid Glacial, Hematoxylin, Eosin, Bouin, Paraffin, Xylol, Aquades, Toluene, and Entellan.

The first method used in this study is Axial Skeleton Calcification, where the observation of the anatomical macro structure of the lizard's tail uses methods including: 1) Morphological structure using a digital camera. 2) The anatomical macro structure with the $X$ - 
Ray method. 3) Full preparation with Alizarin Red S and Alcian Blue staining methods. As for the anatomical microstructure of the lizard's tail using 2 methods including: 1) Slices Preparation Using Hematoxylin and Eosin Staining Methods. 2) Slices Preparation by Using Mallory Triple Stain Coloring Method (Suntoro, 1983). The second is microstructure of Muscular Segmentation with a method: a). Preparations for Longitudinal Slices Using Hematoxylin and Eosin Staining Method. b). Preparation with the Malory Triple Stain Staining Method.

To find out whether there is a reinforcement of the vertebrae of the regenerate tail caudales among them is observed macroscopically, namely by observing whether there is any reinforcement in the whole tail regenerate preparations from $X$-Ray results, the second way is by microscopic observation, namely by observing the histological picture with HematoxylinEosin staining and Mallory Triple Stain. Meanwhile, to determine the sequence of muscular regenerate tail segmentation process, observations were made on whole preparations and tail regenerate slices preparations made longitudinally with HematoxylinEosin staining and Mallory Triple Stain.

\section{RESULTS AND DISCUSSION}

Based on the research that has been done, the Observation Results are obtained:

\section{Observation of Morphological Structure of Lizard Tails}

Observation of the original lizard's tail (Figure 1) showed that the tail that had not undergone lightcolored autotomy and there was no visible segmentation structure along the tail. The regenerate lizard's tail (Figure 2) is almost the same shape as the original tail, the color of the regenerating tail is darker, covered by scales whose shape and arrangement differ from the original tail. A segmentation structure is seen along the tail. Thus the presence or absence of differences in color, shape and arrangement of lizard tail scales, will be used to determine whether a lizard has experienced autotomy or not. While in the gecko, there is a segment of autotomy on the skin of geckos located next to melanophore, a substance that gives black color to geckos. The gecko's tail has neat circular scales there are also scales that are spotted without melanophore. The autotomy segment is clearly visible, namely the presence of a line encircling the tail of a gecko. One gecko can have an autotomy segment between 15-20 segments. This autotomy segment is similar to steps. The original gecko tail is brightly colored and has a supple texture. Scales on the original gecko tail are circularly arranged. Whereas the gecko regenerate is far different because this regenerate tail has irregular scales, random melanophore besides that the tail texture is stiff because of the absence of autotomy segment or autotomy plain. So, there are significant differences between lizards and geckos that can both perform autotomy (Maria, 1998).

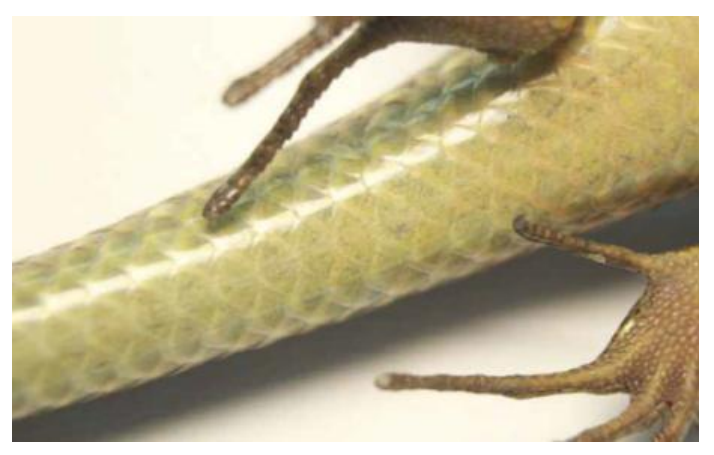

Figure 1. Picture of the tail original lizard, a longitudinal cross section of the ventral.

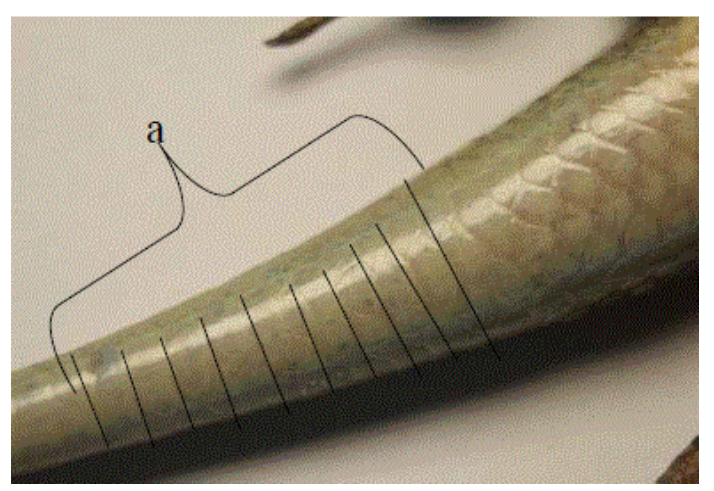

Figure 2. Morphology of a regenerate lizard tail, longitudinal cross section of the ventral. Segmentation of the lizard's tail (a).

\section{Observation of anatomical macro structure by $X$ - Ray method}

Observation using X-Ray (Figure 3) clearly visible vertebrae lizard both from neck to caudal. the regeneration of the lizard's tail (Figure 4) has a tubular bone that extends posteriorly. The muscles that are visible are different, the original tail has segmented muscles while the muscles in the regenerate tail appear innocent without the bulkhead separating it.

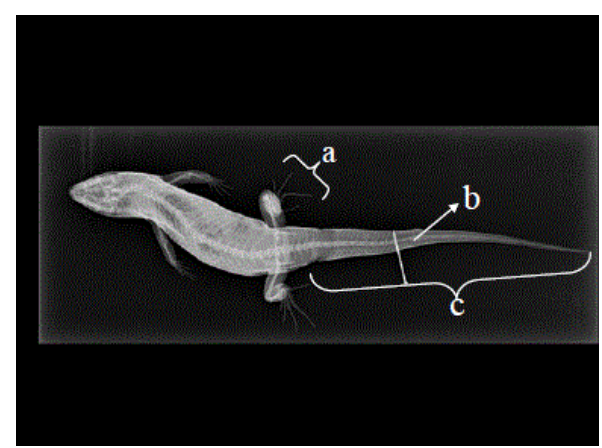

Figure 3. Axial skeleton The tail of an original lizard with $X$-Ray, using an $X$-ray machine with a longitudinal cross section of the dorsal. (a) Femur, (b) Fibula-tibia, (c) Caudal vertebrae, (d) Skin. 


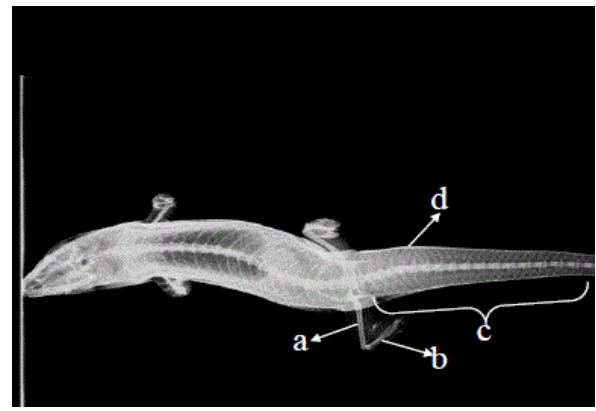

Figure 4. Axial skeleton regenerate Lizard tail with $X$-Ray, using $X$-ray machine with longitudinal cross section of dorsal. (a) Tarsal-metatarsalphalanges/digits, (b) Cartilage tubes, (c) Vertical caudalis.

\section{Observation of whole preparations with Alizarin Red S and Alcian Blue staining method}

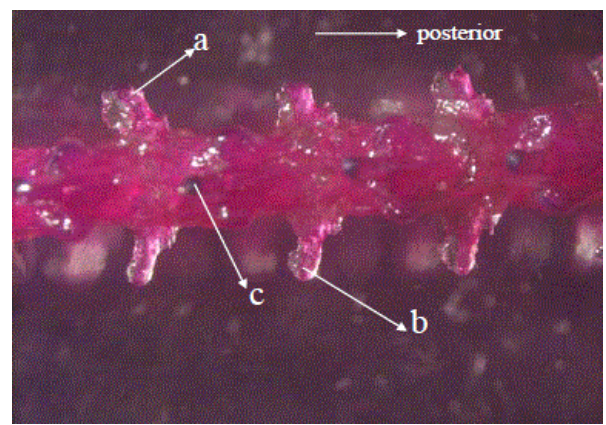

Figure 5. Skeleton axial native lizard tail with Alizarin Red S and Alcian Blue longitudinal section from lateral. (a) Hemal arch, (b) Neural spine, (c) Transverse process.

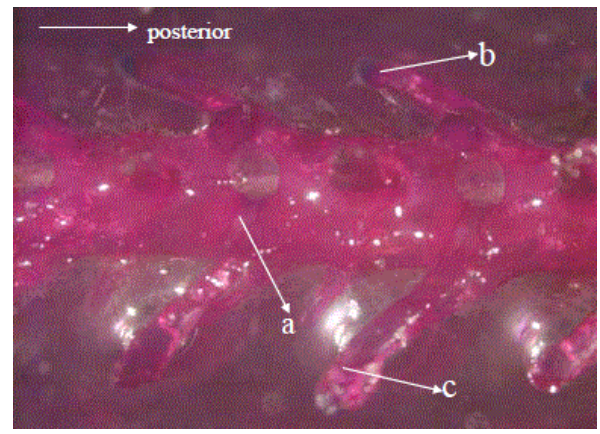

Figure 6. Skeleton axial native lizard tail with Alizarin Red S and Alcian Blue longitudinal section from lateral. (a) Autotomy plain, (b) Hemal arch, (c) Neural spine.

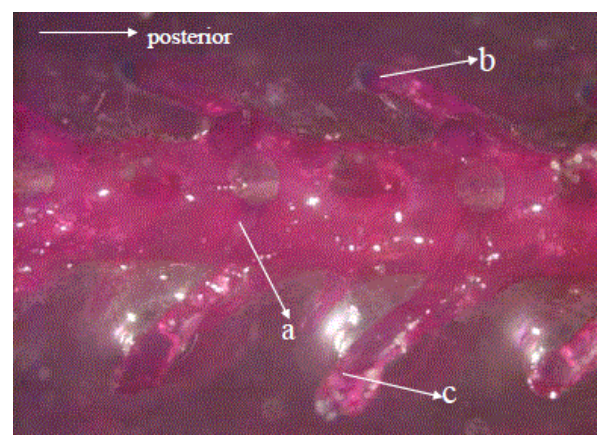

Figure 7. Skeleton axial native lizard tail with Alizarin Red S and Alcian Blue longitudinal section from lateral. (a) Discus Intervertebralis, (b) Hemal arch, (c) Neural Spina.

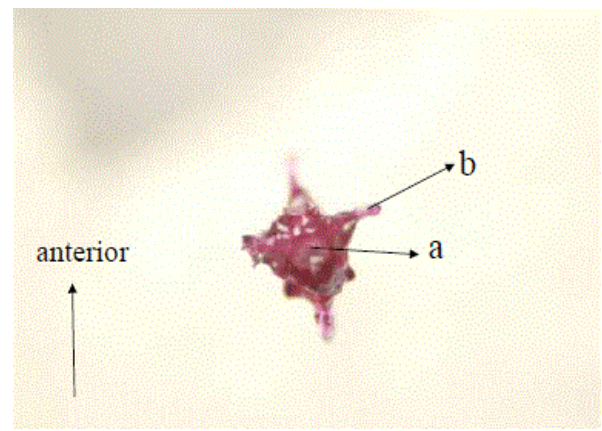

Figure 8. Skeleton axial native lizard tail with Alizarin Red S and Alcian Blue cross section from anterior. (a) Canalis caudales, (b) Transverse process.

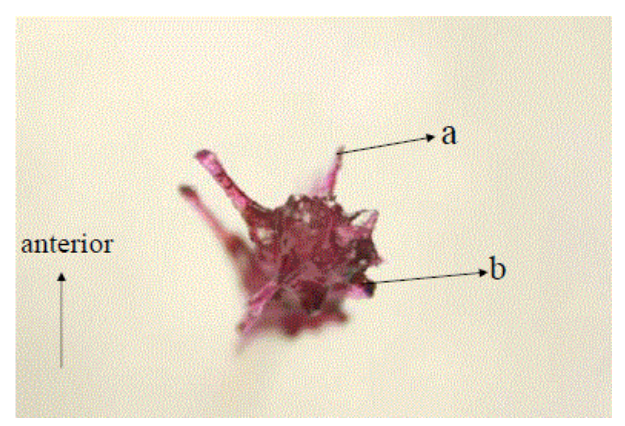

Figure 9. Skeleton axial native lizard tail with Alizarin Red S and Alcian Blue cross section from posterior. (a) Transverse process, (b) Posterior neural spine.

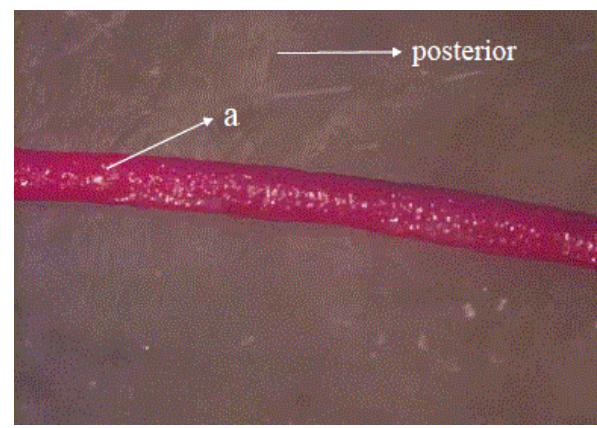

Figure 10. Skeleton axial regenerated lizard tail with Alizarin Red S and Alcian Blue longitudinal section from lateral. (a) Calcified cartilage tubes.

Observation of the original lizard's tail with Alizarin Red S-Alcian Blue from the lateral (Figure 5) shows that the parts of the caudales vertebrae are composed of bone tissue segments, so the tail is dark red. The red color that occurs due to absorption of dye by calcium found in the bone. Staining of the original lizard's tail with Alizarin Red S-Alcian Blue from the lateral (Figure 6) is clearly seen in the autotomy plain. In the bones, the dorsal spine, hemal spine and autotomy plane are seen. The bones are perfectly stained in red, because the bones are composed of calcium. The original lateral lizard tail preparation (Figure 7) also shows that it is composed of bone tissue and discus intervertebrales, dorsal spine and hemal spine are seen. 
In the preparations of the original lizard's tail from anterior (Figure 8) canalis caudales and transverse processus. Likewise, the original lizard bone seen from the posterior (Figure 9) shows the transverse process and the posterior neural spine. Observation of whole regenerated lizard's tail preparations (Figure 10) shows that the tail of the lizard is tubular and is a cartilage tissue, no longer a segmented bone that has a process, atutotomy plateau.

The tail regenerator has vertebrae caudales that are left from the original tail as a place to attach the cartilage tube. Lizard's tail regeneration cannot experience autotomy due to tubular bone that has no autotomy or bone parts that cause autotomy. Whereas the gecko on Alizarin Red S-Alcian Blue staining shows chevron, centrum, spinal cord (Maria, 1998). According to Luthfi (2002), calcification (ossification) or ossification processes will cause the cartilage tube to be red on the outside. The red color is caused by the presence of the Red S Alcian Blue Alizarin dye stuff with calcium ions. If the color gets red (dark red), the calcium ions in the cartilage tube increase and show that the calcification process is perfect. Whereas the tail of the gecko also shows its calcification perfectly because it is red on the outside (Maria, 1998). Observations on transverse slice preparations in the original lizard tail (Mabouya multifasciata kuhl) with hematoxylin-eosin staining and Mallory acid fuchsin showed that the skin or dermis in the lizard's tail was very thin, vertebral joints were procela type. The purple color of the preparation is the cell nucleus which is colored by hematoxylin, while the pink color that is colored by eosin is cytoplasm. Mallory acid fuchsin preparations show bright blue collagen fibers. While the nucleus, cytoplasm elastic fibers and fibrin are red. Erythrocytes and orange myelin fibers.

\section{Observation of the microstructure of the anatomy of the lizard's tail}

\section{Preparation of Slice Preparations Using Hematoxylin and Eosin Staining Methods}

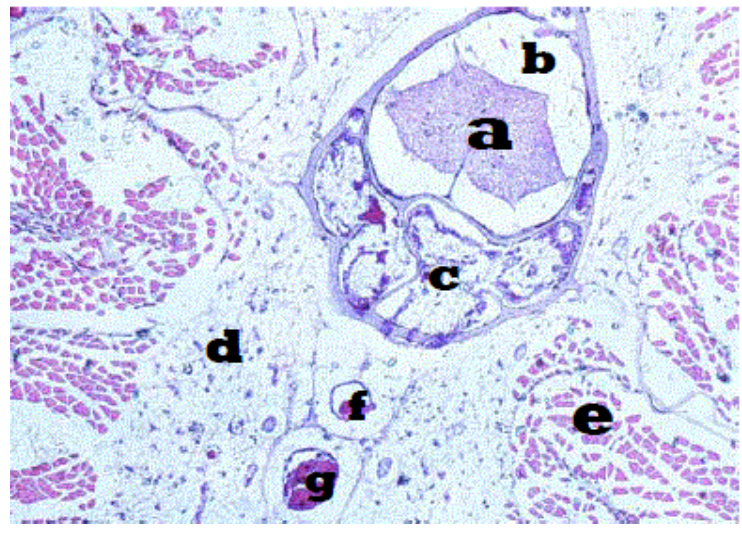

Figure 11. Cross section of the original lizard's tail, Hematoxylin-Eosin staining. 4x10 zoom. (a) Spinal cord, (b) Vertebral canal, (c) Centrum vertebrae, (d) Perivertebral fat tissue, (e) Muscle, (f) Caudales artery, (g) Veins caudales.

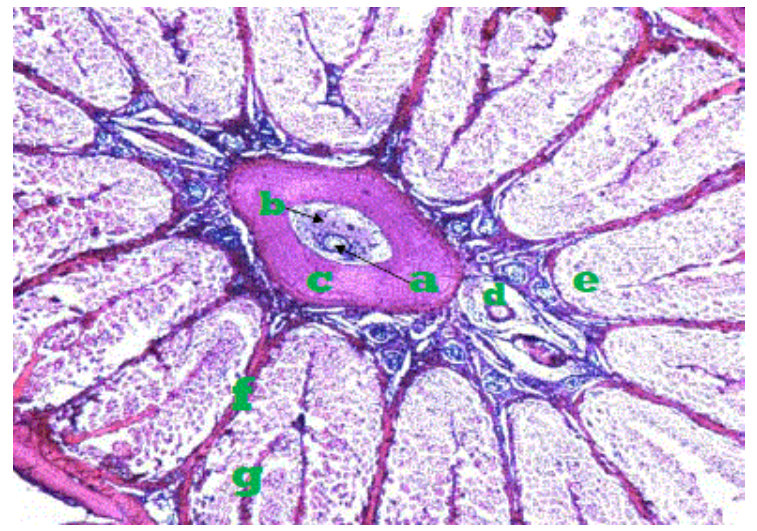

Figure 12. Cross section of regenerated lizard tail. Hematoxylin-Eosin staining, 4x10 magnification. (a) Ependymocyti, (b) Meninx Tube, (c) Cartilage, (d) Caudal artery, (e) Muscle, (f) Muscle segment, (g) Myotome.

Observations on transverse incisions in the original lizard with hematoxylin-eosin staining (Figure 11) and mallory triple stain (Figure 12) were seen in the spinal cord, vertebral canal, centrum vertebrae, perivertebral fat and muscle tissue. In the regenerate lizard's tail does not have a spinal cord, whereas in the original lizard tail has a spinal cord. The vertebral canal is located adjacent to the centrum of the vertebrae on the outside there is perivertebral fat and muscle tissue.

\section{Observation of Transverse Slice Preparation Using the Mallory Triple Stain Staining Method}

Observations on regenerate transverse slices in lizard's tails with hematoxylin-eosin staining (Figure 13) and mallory triple stain (Figure 14) showed that the regenerate tail was not supported by bone but supported by a non-segmental cartilage tube. Inside the cartilage tube there is meninx and ependymocyti which are located parallel to the cartilage tube. Research conducted by Rachman and Luthfi (2004) says that this calcification or ossification process starts from the inner and outer sides of the cartilage tube. Observation of longitudinal slice preparation (Figure 15) shows only cartilage or cartilage tubes. In the cartilage tube there is an ependima layer that is located parallel to the cartilage tube. According to Soesilo (1999), the ependima layer is very influential in the process of tail regeneration and in the formation of cartilage tubes containing cartilage cells. Observations on transverse preparations of muscular segmentation of the original lizard's tail with hematoxylin-eosin staining and mallory triple stain showed that the muscle segments of the original lizard's tail had only irregular muscle segments. Whereas the regenerated lizard's tail with hematoxylin-eosin staining and mallory triple stain showed that the muscle was segmented, in contrast to the original tail. In the lizard regenerate segment, it has 15 segments. From the picture, the staining using Mallory acid fuchsin shows the tail regenerate tissue, indicating that the tail regenerate muscle is composed 
of several myotubes that join to form myotomes and each myotomes are separated by myoseptum or septum. While the gecko tail segment has 12 segments. There are differences between muscle segments of lizards and geckos, there are 15 segments in lizards, while in geckos there are only 12 segments (Maria, 1998).

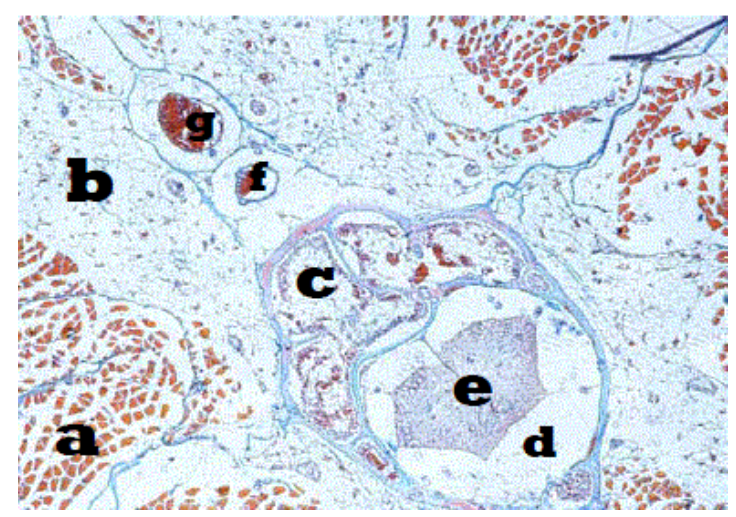

Figure 13. Cross section of native lizard tail, Mallory Triple Stain staining, 4x10 magnification. (a) Muscles, (b) Perivertebral fat tissue, (c) Centrun vertebrae, (d) Vertebral canalis, (e) Spinal cord, (f) Caudales artery, (g) Veins caudales.

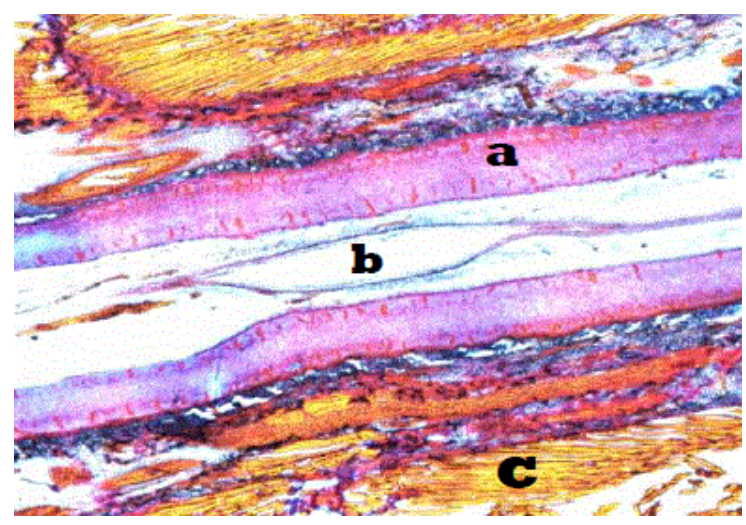

Figure 14. Regenerated lizard longitudinal cross section, Mallory Triple Stain staining, 4x10 enlargement. (a) Cartilage tube, (b) Ependymocyte, (c) Muscle.

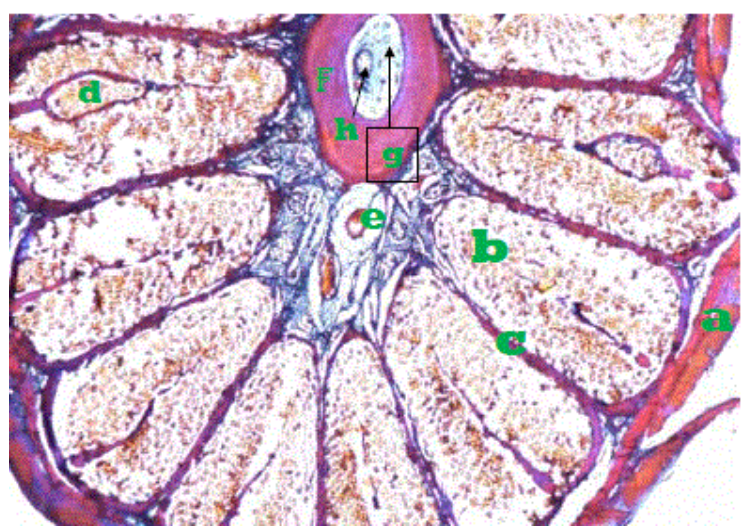

Figure 15. Cross section of regenerat lizard tail, Mallory Triple Stain staining, 4x10 magnification. (a) skin, (b) Muscle, (c) Muscle segment, (d) Myotomes, (e) Caudales artery, (f) Cartilago tube, (g) Meninx, (h) Ependymocyti.

\section{CONCLUSIONS}

Based on the observations, the following conclusions are obtained the color of the regenerate tail is darker compared to the original tail. In the original lizard's tail when seen using $X$-Ray and the original tail alizarin staining will look broad and have a process. The original lizard's tail is composed of bones, because it is red which shows perfectly calcified bones. While the regeneration of the lizard's tail is composed of cartilage which is shaped like a long, red-piped pipe on the outside because it has calcified.

The muscle segment of the original lizard's tail when viewed transversely only has an irregular muscle segment. While the regeneration of the lizard's tail when viewed transversely visible muscle segments amounting to 15. Muscles are composed of a collection of myotubes that form myotomes, each myotomes are limited by myoseptum.

\section{ACKNOWLEDGMENTS}

The author would like to thank to the management of apprenticeship program of faculty of science and technology for guidance during the research, to the management of biology, medicine and natural product chemistry \& kaunia journal for assistance in paper writing.

\section{REFERENCES}

Bustard, H. R. 1968. Temperatur Dependant Tail Autotomy Mekanism in Geckkonoid lizard. Herpetologica. Hal 127-130.

Luthfi, M. J, Soesilo, N.P, Sagi, M. 2003. Kalsifikasi Skeleton Aksial pada Regenerat Ekor Kadal (Mabouya multifasciata Kuhl). Jurnal Berkala Ilmiah Biologi, Vol. 3, No. 1: 1-8. Yogyakarta: Universitas Gadjah Mada.

Luthfi, M. Jafar. 2002. Kalsifikasi Skeleton Aksial dan Kemampuan Autotomy Regenerat Ekor Kadal (Mabouya multifasciata $k u h l)$.Tesis. Universitas Gajah Mada (Tidak Dipublikasikan).

Maria, B. 1998. Struktur Vertebrae Caudales pada 5 Species Anggota Sub Ordo Lacertilia. Skripsi. Universitas Gadjah Mada (Tidak Dipublikasikan).

Soesilo, N. P. 1992. Proses Regenerasi Ekor Kadal (Mabouya multifasciata Kuhl). Biologi, Vol. 1, No. 4: 169-175.

Soesilo, N.P. 1999. Peranan Lapisan Ependima dalam Regenerasi Ekor Kadal (Mabouya multifasciata Kuhl), Biologi, Vol. 2, No.8: 419-450.

Suntoro, Handari. 1983. Metode Pewarnaan. Bhratara Karya Aksara. Jakarta. Hal 221-233. 
THIS PA GE INTENTIONALLY LEFT BLANK 